\title{
Sistem Pendukung Keputusan Untuk Menentukan Tujuan PPL Mahasiswa Menggunakan Metode AHP
}

\author{
Rahmad Al Rian ${ }^{1}$, Ambiyar ${ }^{2}$, Edi Ismanto ${ }^{3}$ \\ Program Studi Pendidikan Informatika Universitas Muhammadiyah Riau, Sukajadi, Pekanbaru, \\ Riau $^{(1 \text { dan } 3)}$ \\ Jl. Tuanku Imam Bonjol Pekanbaru \\ Program Studi Teknik Mesin Universitas Negeri Padang, Padang, Sumatera Barat ${ }^{(2)}$ \\ Jl. Prof. Dr. Hamka, Air Tawar, Padang \\ ${ }^{1}$ rahmadalrian@umri.ac.id \\ ªmbiyar@ft.unp.ac.id \\ 3edi.ismanto@umri.ac.id
}

\begin{abstract}
Abstrak
Praktek Pengalaman Lapangan (PPL) merupakan kegiatan yang dilakukan mahasiswa Fakultas Keguruan dan Ilmu Pendidikan untuk menerapkan keilmuan kompetensi yang telah dipelajari selama perkuliahan. Kegiatan ini dengan menempatkan mahasiswa pada sekolah menengah kejuruan negeri atau swasta di wilayah kota Pekanbaru. Penempatan mahasiswa sering tidak sesuai dengan keahlian mahasiswa tersebut sehingga mahasiswa tidak mampu mengajar dengan kemampuan terbaik berdasarkan bidang keilmuan program studi pada sekolah yang menjadi tujuan. Penelitian yang akan dilakukan adalah untuk membangun sistem pendukung keputusan dengan menggunakan metode Analytical Hierarcy Process yang disingkat AHP dengan mengkolaborasikan data program studi pada sekolah kejuruan yang berhubungan dengan data nilai akademik mahasiswa untuk menentukan tujuan Praktek Kerja Lapangan per Mahasiswa.
\end{abstract}

Kata kunci - Decision Support System, Analytical Hierarcy Process, Consistency Ratio, Informatics Education Study Program, Vocational Education

Abstract
Internship or PPL is an activity carried out by the Faculty of Teachers Training and Education students to apply their scientific competencies which have been learned during lectures in the University. It is by placing students in public or private vocational secondary schools in the city of Pekanbaru. Student placement is often not in accordance with the students expertise so that they are not able to teach with the best efforts and ability which based on scientific field of study program at the destination school. This research is to build a decision support system by using Analytical Hierarchy Process (AHP) by collaborating data in vocational school study program with student academic score data to determine the objectives of internship per student.

Keywords - Decision Support System, Analytical Hierarcy Process, Consistency Ratio, Informatics Education Study Program, Vocational Education

\section{Pendahuluan}

Perkembangan teknologi informasi mampu mendukung pengambilan keputusan dengan cepat berdasarkan informasi yang diberikan kedalam sistem informasi [1] sehingga mampu 
mendukung analisa data dan memodelkan pengambilan keputusan [2] karena keputusan tersebut melibatkan banyak faktor [3].

Skill teknologi yang dimiliki oleh seseorang akan memberikan nilai kualitas yang tinggi karena semakin dibutuhkannya sumber daya manusia yang memiliki skill teknologi pada seluruh instansi pemerintahan dan swasta. Pada bidang pendidikan yaitu pada taman kanak kanak dan setingkatnya, tingkat sekolah dasar dan setingkatnya, sekolah menengah pertama dan setingkatnya, sekolah menengah atas dan setingkatnya serta sekolah tinggi telah melampirkan keilmuan komputer pada kurikulumnya. Untuk meningkatkan kualitas sumber daya manusia yang berada pada tingkat sekolah menengah atas, dibutuhkan tenaga pendidik yang memiliki skill keilmuan komputer yang berkualitas sehingga sekolah tersebut mampu menghasilkan lulusan yang menjadi sumber daya manusia berkualitas pada bidang teknologi.

Pemerintah Indonesia [4] telah mengelompokkan program pendidikan untuk Sekolah Menengah Kejuruan (SMK) menjadi beberapa bidang keahlian dengan beberapa program studi keahlian yang dipersiapkan sebagai wadah pendidikan untuk generasi muda bangsa. Untuk mengajar dan membimbing generasi muda bangsa, dibutuhkan guru yang kompeten secara skill sehingga mampu membentuk dan mengembangkan skill para generasi muda.

Calon mahasiswa yang melaksanakan pendidikan memiliki latar belakang pendidikan jurusan SMA/SMK/MA yang berbeda. Selama proses perkuliahan diprogram studi Pendidikan Informatika, mahasiswa yang merupakan calon guru diajarkan berbagai teknologi informasi seperti algoritma dan pemrograman, komunikasi data dan jaringan komputer dan multimedia.

Sementara pada sekolah kejuruan, tersedia program studi yang berhubungan dengan pendidikan informatika diwilayah kota Pekanbaru yaitu:

1. Rekayasa Perangkat Lunak

2. Teknik Komputer dan Jaringan

3. Desain Komunikasi Visual

4. Animasi

5. Persiapan Grafika

Dengan demikian, dibutuhkan cara khusus untuk menentukan pejurusan penempatan praktik kerja lapangan dengan suatu metode yang mampu mendukung proses pengambilan keputusan dan mampu diintegrasikan pada sistem komputer untuk perhitungan yang akurat sehingga ketika masa praktik kerja lapangan, sistem pendukung keputusan ini mampu memberikan informasi kelayakan untuk penempatan mahasiswa PPL pada sekolah kejuruan tersebut.

Pada tahun ajaran 2017/2018, program studi Pendidikan Informatika telah menyebarkan mahasiswa untuk melaksanakan PPL dengan rincian sebagai berikut:

Tabel 1. Sebaran Mahasiswa Program Studi Pendidikan Informatika Wilayah Kota Pekanbaru

\begin{tabular}{|c|c|c|c|}
\hline No. & Nama & $\begin{array}{l}\text { Sekolah Mitra / } \\
\text { Tempat PPL }\end{array}$ & $\begin{array}{l}\text { Jurusan / } \\
\text { Kompetensi } \\
\text { di Sekolah }\end{array}$ \\
\hline 1 & Puput Reza Renzani & \multirow{3}{*}{$\begin{array}{l}\text { SMK KANSAI } \\
\text { PEKANBARU }\end{array}$} & TKJ \\
\hline 2 & Yuliani & & TKJ \\
\hline 3 & Rahmawati & & TKJ \\
\hline 4 & Arman Ridwansyah & \multirow{2}{*}{$\begin{array}{l}\text { SMK DAREL } \\
\text { HIKMAH } \\
\text { PEKANBARU }\end{array}$} & Multimedia \\
\hline 5 & Fitria Wati & & Multimedia \\
\hline
\end{tabular}




\begin{tabular}{|c|c|c|c|}
\hline 6 & Lia Ardani Nasution & & Multimedia \\
\hline 7 & T. Helni Setriyani & \multirow{3}{*}{$\begin{array}{c}\text { MA } \\
\text { MUHAMMADIYAH } \\
\text { PENYESAWAN }\end{array}$} & IPS \\
\hline 8 & Anita Putri & & IPS \\
\hline 9 & Amaliya Gusniati & & IPS \\
\hline 10 & Joti Blas Santi & \multirow{4}{*}{$\begin{array}{l}\text { SMA N } 1 \\
\text { TAMBANG }\end{array}$} & IPA \& IPS \\
\hline 11 & Reni Oktavia & & IPA \& IPS \\
\hline 12 & Nursafirah & & IPA \& IPS \\
\hline 13 & Yuli Nelvi & & IPA \& IPS \\
\hline 14 & Alya Andriani Putri & \multirow{3}{*}{$\begin{array}{c}\text { SMK N } 3 \\
\text { PEKANBARU }\end{array}$} & Multimedia \\
\hline 15 & Diah Eka Ratna & & Multimedia \\
\hline 16 & Yaldi Defrianda & & Multimedia \\
\hline 17 & Kiki Andrestra Putri & \multirow{4}{*}{$\begin{array}{l}\text { SMK LABOR } \\
\text { PEKANBARU }\end{array}$} & $\begin{array}{l}\text { TKJ dan } \\
\text { RPL }\end{array}$ \\
\hline 18 & Sridevi Malinda & & RPL \\
\hline 19 & $\begin{array}{l}\text { Tesya Gustia } \\
\text { Syafron }\end{array}$ & & $\begin{array}{l}\text { TKJ dan } \\
\text { RPL }\end{array}$ \\
\hline 20 & Nurianda Kinanti & & $\begin{array}{l}\text { TKJ dan } \\
\text { RPL }\end{array}$ \\
\hline
\end{tabular}

Berdasarkan data tersebut, mampu dilihat bahwa penyebaran mahasiswa PPL prodi Pendidikan Informatika FKIP UMRI belum sesuai dengan kompetensi yang dimiliki oleh mahasiswa tersebut. Ini terlihat masih disebarkan untuk jurusan IPS dan IPA. Identifikasi masalah yang dibahas adalah "Bagaimana merancang sistem informasi pendukung keputusan yang mampu menentukan penempatan tempat PPL mahasiswa program studi Pendidikan Informatika?".

Tujuan penelitian ini untuk menemukan pola penentuan lokasi PPL mahasiswa berdasarkan kompetensi mahasiswa dengan menggunakan metode AHP sehingga mampu menjadi sistem pendukung keputusan pada penentuan penjurusan berdasarkan minat dan bakat mahasiswa program studi Pendidikan Informatika sebagai calon guru. Kompetensi yang berasal dari kemampuan mahasiswa karena akan berpengaruh pada perkembangan kualitas kompetensi para calon guru dalam melakukan tugas mengajar dan membimbing

Spektrum Keahlian Pendidikan Menengah Kejuruan (PMK) adalah jenis-jenis program pendidikan serta syarat - syarat penyelenggaraannya, sebagai panduan untuk membuka dan mengembangkan program pendidikan pada SMK/MAK karena jurusan-jurusan yang dikembangkan di SMK/MAK bentuknya adalah keahlian-keahlian atau jabatan-jabatan pekerjaan (job titles) yang ada dan berkembang di dunia kerja, jadi bukan didasarkan atas disiplin keilmuan. Spektrum Keahlian yang saat ini berlaku adalah berdasarkan Keputusan Direktur Jenderal Pendidikan Menengah Kementerian Pendidikan dan Kebudayaan Nomor 
7013/D/KP/2013, Spektrum Keahlian PMK terdiri atas 9 (sembilan) Bidang Keahlian, 46 Program Keahlian, dan 128 Paket Keahlian [5].

Tabel 2 : Rekapitulasi Daftar Program Keahlian Pendidikan Menengah Kejuruan

\begin{tabular}{|l|c|c|}
\hline \multicolumn{1}{|c|}{ BIDANG KEAHLIAN } & \multicolumn{1}{|c|}{$\begin{array}{c}\text { PROGRAM } \\
\text { KEAHLIAN }\end{array}$} & $\begin{array}{c}\text { PAKET } \\
\text { KEAHLIAN }\end{array}$ \\
\hline 1. Teknologi dan Rekayasa & 18 & 7 \\
\hline $\begin{array}{l}\text { 2. Teknik Informasi dan } \\
\text { Komunikasi }\end{array}$ & 3 & 6 \\
\hline 3. Kesehatan & 2 & 16 \\
\hline 4. Agribisnis dan Agroteknologi & 6 & 8 \\
\hline 5. Perikanan dan Kelautan & 3 & 5 \\
\hline 6. Bisnis dan Manajemen & 3 & 7 \\
\hline 7. Pariwisata & 4 & 7 \\
\hline 8. Seni Rupa dan Kriya & 2 & 128 \\
\hline 9. Seni Pertunjukan & 5 & 46 \\
\hline \multicolumn{1}{|c|}{ JUMLAH } & & 70 \\
\hline
\end{tabular}
berikut.

Spektrum Keahlian Pendidikan Menengah Kejuruan ditetapkan dengan tujuan sebagai

1. Memberikan acuan dalam pengembangan dan penyelenggaraan program pendidikan di SMK/MAK, khususnya dalam pembukaan dan penyelenggaraan bidang / program/paket keahlian;

2. Memberikan acuan dalam pengembangan kurikulum dan pembelajaran;

3. Menentukan tingkat efektivitas dan relevansi pendidikan pada SMK/MAK,

4. Memberikan acuan untuk pelaksanaan penilaian dan akreditasi SMK/MAK.

Untuk kompetensi kejuruan Rekayasa Perangkat Lunak, Teknik Komputer dan Jaringan, Desain Komunikasi Visual, Animasi dan Persiapan Grafika, spektrum keahlian terlihat pada tabel di bawah ini:

Tabel 3 : Paket Keahlian Kompetensi Yang Releven dengan Prodi Pendidikan Informatika

\begin{tabular}{|c|l|l|l|}
\hline NO. & \multicolumn{1}{|c|}{ BIDANG KEAHLIAN } & PROGRAM KEAHLIAN & \multicolumn{1}{|c|}{ PAKET KEAHLIAN } \\
\hline 1 & Teknologi dan Rekayasa & Teknik Grafika & Persiapan Grafika \\
\hline 2 & Seni Rupa dan Kriya & Seni Rupa & Animasi \\
\hline 3 & \multirow{2}{*}{\begin{tabular}{l} 
Teknologi Informasi dan \\
\cline { 1 - 1 }
\end{tabular}} & $\begin{array}{l}\text { Teknik Komputer dan } \\
\text { Komunikasi }\end{array}$ & Rekayasa Perangkat Lunak \\
\cline { 1 - 1 } & & Teknik Jaringan Komputer \\
& & & Multi-media \\
\hline
\end{tabular}

Program studi Pendidikan Informatika Universitas Muhammadiyah Riau memiliki 29 mata kuliah dan 124 materi kajian. Untuk tingkat SMK berdasarkan Keputusan Direktur Jenderal Pendidikan Dasar dan Menengah nomor 130/D/KEP/KR/201 tentang Struktur Kurikulum Pendidikan [6], kompetensi Rekayasa perangkat lunak memiliki 9 mata pelajaran, 
teknik komputer dan jaringan memiliki 8 mata pelajaran, multimedia memiliki 8 mata pelajaran, desain komunikasi visual memiliki 11 mata pelajaran, animasi memiliki 10 mata pelajaran.

\section{Metode Penelitian}

Analytical Hierarchy Process [7] adalah suatu keputusan yang berdasarkan pada perhitungan aritmatika dan psikologi manusia. AHP juga merupakan [8] metode yang digunakan untuk menghasilkan solusi dari permasalahan kompleks dan tidak terstruktur berdasarkan masing - masing variabel dan kepentingan relatif masing - masing variabel, melakukan sintesis untuk menentukan variabel mana yang memiliki nilai.

Untuk merancang sistem pengambilan keputusan, terdapat model yang berlaku pada sistem pengambilan keputusan [9] seperti yang terlihat pada gambar di bawah:

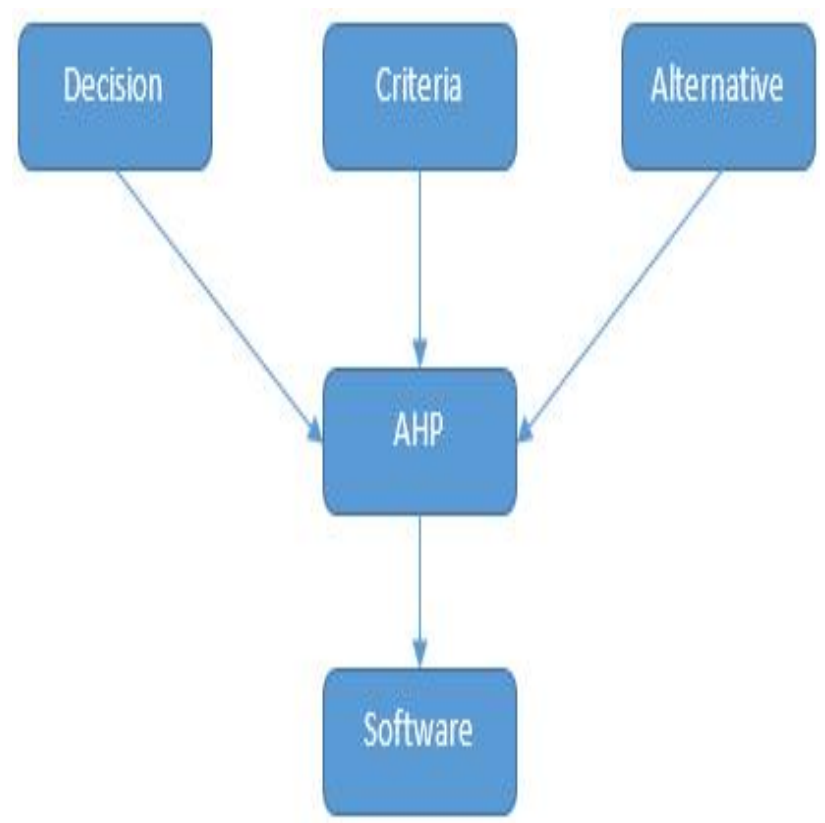

Gbr.1 Decision Support System Model

Sementara untuk komponen Sistem Pendukung Keputusan [10], terlihat dari gambar 2 dibawah ini dimana user interface harus didesain dengan baik sebagai media penghubung pengguna dengan sistem pendukung keputusan. Kemudian juga harus memiliki metode manajemen data yang merupakan subsistem sistem pendukung keputusan. 


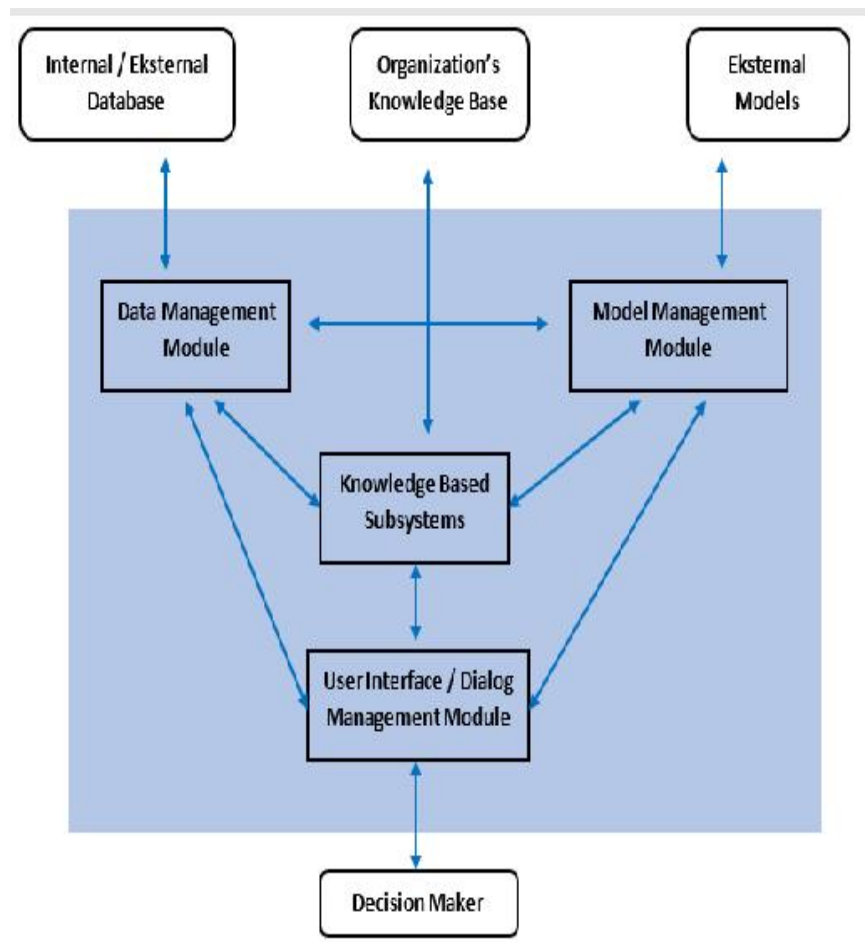

Gbr.2 Decision Support System Components

Penulis menghitung jumlah mata kuliah yang ada di program studi Pendidikan Informatika dan melakukan pengelompokkan berdasarkan paket keahlian kompetensi. Terlihat pada tabel di bawah ini:

Tabel 4 : Keterhubungan Jumlah Mata Kuliah program Studi Pendidikan Informatika dengan Kompetensi Paket Keahlian

\begin{tabular}{|c|l|c|c|}
\hline No. & \multicolumn{1}{|c|}{$\begin{array}{c}\text { Kompetensi } \\
\text { Paket Keahlian }\end{array}$} & \multicolumn{2}{|c|}{$\begin{array}{c}\text { Mata Kuliah } \\
\text { Yang Relevan }\end{array}$} \\
\cline { 3 - 4 } & Jumlah & $\begin{array}{c}\text { Prioritas } \\
\text { AHP }\end{array}$ \\
\hline 1 & $\begin{array}{l}\text { Rekayasa } \\
\text { Perangkat Lunak }\end{array}$ & 17 & 5 \\
\hline 2 & $\begin{array}{l}\text { Teknik Komputer } \\
\text { Jaringan }\end{array}$ & 7 & 4 \\
\hline 3 & Multimedia & 6 & 3 \\
\hline 4 & Animasi & 5 & 2 \\
\hline 5 & $\begin{array}{l}\text { Desain } \\
\text { Komunikasi } \\
\text { Visual }\end{array}$ & 4 & 1 \\
\hline
\end{tabular}

Berdasarkan data yang penulis dapatkan, ada 20 mahasiswa yang ditugaskan untuk PPL ke sekolah - sekolah. Dengan demikian, perhitungan AHP mampu dilakukan.

Tabel 5 : Matriks Perbandingan Berpasangan

\begin{tabular}{|c|c|c|c|c|c|}
\hline $\begin{array}{c}\text { Kom- } \\
\text { peten- } \\
\text { si }\end{array}$ & DKV & Animasi & $\begin{array}{c}\text { Multi- } \\
\text { media }\end{array}$ & TKJ & RPL \\
\hline DKV & 1 & 0,5 & 0,33 & 0,25 & 0,2 \\
\hline
\end{tabular}




\begin{tabular}{|l|c|c|c|c|c|}
\hline $\begin{array}{l}\text { Ani- } \\
\text { masi }\end{array}$ & 2 & 1 & 0,67 & 0,5 & 0,4 \\
\hline $\begin{array}{l}\text { Multi- } \\
\text { media }\end{array}$ & 3 & 1,5 & 1 & 0,75 & 0,6 \\
\hline TKJ & 4 & 2 & 1,33 & 1 & 0,8 \\
\hline RPL & 5 & 2,5 & 1,67 & 1,25 & 1 \\
\hline Jumlah & 15 & 7,5 & 5 & 3,75 & 3 \\
\hline
\end{tabular}

Setelah berhasil melakukan perhitungan seperti tabel diatas, dilakukan perhitungan untuk matriks faktor pembobotan hirarki untuk semua kriteria seperti yang terlihat pada tabel di bawah.

Tabel 6 : Matriks Faktor Pembobotan Hirarki Yang Disederhanakan

\begin{tabular}{|c|c|c|c|c|c|c|c|}
\hline Kompetensi & DKV & Animasi & Multimedia & TKJ & RPL & Jumlah & Rerata \\
\hline DKV & 0,07 & 0,07 & 0,07 & 0,07 & 0,07 & 0,33 & 0,07 \\
\hline Animasi & 0,13 & 0,13 & 0,13 & 0,13 & 0,13 & 0,67 & 0,13 \\
\hline Multimedia & 0,2 & 0,2 & 0,2 & 0,2 & 0,2 & 1 & 0,2 \\
\hline TKJ & 0,27 & 0,27 & 0,27 & 0,27 & 0,27 & 1,33 & 0,27 \\
\hline RPL & 0,33 & 0,33 & 0,33 & 0,33 & 0,33 & 1,67 & 0,33 \\
\hline Jumlah & 1 & 1 & 1 & 1 & 1 & 1 & 1 \\
\hline
\end{tabular}

Setelah berhasil mendapatkan hasil perhitungan matriks faktor pembobotan hirarki yang disederhanakan, dilakukan perhitungan untuk matriks pembobotan hirarki yang dinormalkan seperti pada tabel di bawah ini.

Tabel 7 : Matrik Pembobotan Hirarki Yang Dinormalkan

\begin{tabular}{|c|c|c|c|c|c|c|c|c|}
\hline Kompetensi & DKV & Animasi & Multimedia & TKJ & RPL & \multirow{6}{*}{$\mathrm{X}$} & Vektor & Hasil \\
\hline DKV & 1 & 0,5 & 0,33 & 0,25 & 0,2 & & 0,07 & 0,33 \\
\hline Animasi & 2 & 1 & 0,67 & 0,5 & 0,4 & & 0,13 & 0,67 \\
\hline Multimedia & 3 & 1,5 & 1 & 0,75 & 0,6 & & 0,2 & 1 \\
\hline TKJ & 4 & 2 & 1,33 & 1 & 0,8 & & 0,27 & 1,33 \\
\hline RPL & 5 & 2,5 & 1.67 & 1.25 & 1 & & 0,33 & 1.67 \\
\hline
\end{tabular}

Lambda maksimal $\quad=1$

Consistency Index $\quad=-4 / 4$

$$
=-1
$$

Consistency Responden $=-1 / 1.12$

$$
=-0,89286
$$

Untuk mendapatkan jumlah mahasiswa yang akan dikirim mengikuti kegiatan PPL berdasarkan kompetensi paket keahlian yang ada di SMK wilayah Pekanbaru, kita lakukan perhitungan sebagai berikut:

1. Rerata yang ada pada tabel 6 dikonversi dalam bentuk persentase sehingga menjadi $6.67 \%$, $13.33 \%, 20 \%$, 26.67\%, dan $33.33 \%$.

2. Untuk mendapatkan jumlah mahasiswa yang akan dikirim pada setiap paket keahlianilai persentase tersebut dikali dengan jumlah mahasiswa yang akan dikirim, yaitu 20 orang sehingga menghasilkan data yang tertera pada tabel 8 dibawah ini. 
Tabel 8 : Pengelompokan Bakat Mahasiswa Berdasarkan Nilai dan Paket Keahlian Kompetensi

\begin{tabular}{|c|l|c|}
\hline No. & \multicolumn{1}{|c|}{ Paket Keahlian Kompetensi } & Jumlah Mahasiswa \\
\hline 1 & Rekayasa Perangkat Lunak (RPL) & 7 orang \\
\hline 2 & Teknik Komputer dan Jaringan (TKJ) & 5 orang \\
\hline 3 & Multimedia & 4 orang \\
\hline 4 & Animasi & 3 orang \\
\hline 5 & Desain Komunikasi Visual (DKV) & 1 orang \\
\hline \multicolumn{2}{|r|}{ TOTAL MAHASISWA } & 20 orang \\
\hline
\end{tabular}

Setelah mengetahui jumlah mahasiswa yang harus dikirim untuk setiap paket keahlian kompetensi, pengembangan sistem pendukung keputusan harus mampu mendukung tahapan :

1. Perhitungan jumlah mahasiswa yang akan dikirim untuk setiap paket keahlian kompetensi.

2. Memberikan usulan atau menentukan mahasiswa yang akan dikirim pada setiap kompetensi keahlian pada program PPL.

Penentuan skala prioritas pada kompetensi paket keahlian dilakukan secara manual oleh administrator sistem dengan memberikan nilai prioritas pada setiap kompetensi paket keahlian berdasarkan kesepakatan yang telah disepakati pada forum dosen fakultas. Dengan keputusan yang telah disepakati akan terbentuk nilai pada form penentuan prioritas kompetensi seperti gambar di bawah.

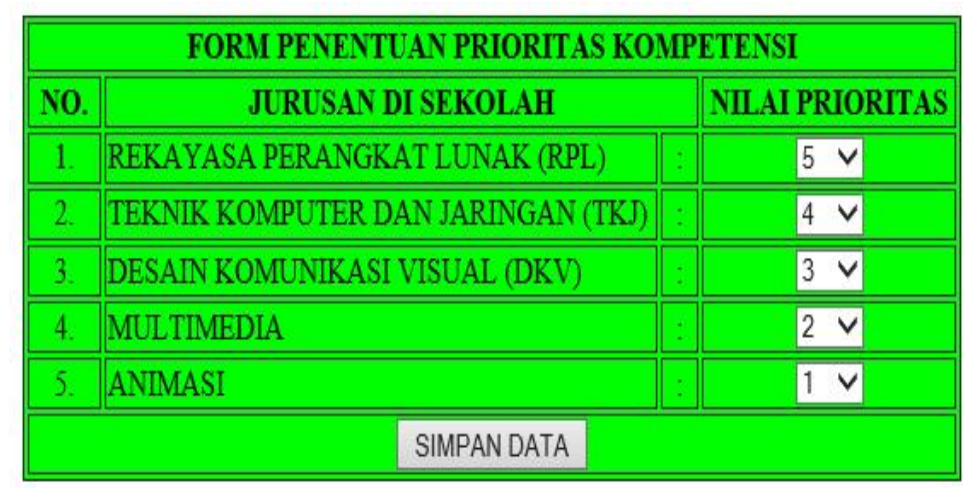

Gbr.3 Form Penentuan Prioritas Kompetensi

Setelah nilai prioritas ditentukan, dilakukan perhitungan dengan metode AHP oleh sistem berdasarkan nilai prioritas kompetensi yang terlihat pada gambar 3. Setelah proses tersebut, dihasilkan perhitungan matrik pembobotan hirarki yang disederhanakan seperti yang terlihat pada gambar 4 di bawah.

\begin{tabular}{|c|c|c|c|c|c|c|c|}
\hline \multicolumn{8}{|c|}{ MATRIKS PENBOBOTAV HIERARCHY YANG DISEDERHAVAKAN } \\
\hline MATRIK & DKV & ANIMASI & MULTINEDIA & TKJ & RPL & JТМLAH & RERATA \\
\hline $\mathrm{DKV}$ & $0,0 ?$ & 0,07 & 0,07 & 0,07 & 0,07 & 0,33 & $0,0,0$ \\
\hline AYIMASI & 0,13 & 0,13 & 0,13 & 0,13 & 0,13 & 0,67 & 0,13 \\
\hline MILTIMEDLA & 0,2 & 0,2 & 0,2 & 0,2 & 02 & 1 & 0,2 \\
\hline TKJ & 0,27 & 0.27 & 0.27 & 0,27 & $0,2 \pi$ & 1,33 & 0,27 \\
\hline RPL & 0,33 & 0,33 & 0,33 & 0,33 & 033 & $16 ?$ & 0,33 \\
\hline JULAH & 1 & 1 & 1 & 1 & 1 & 5 & 1 \\
\hline
\end{tabular}

Gbr.4 Matrik Pembobotan Yang Disederhanakan 
Setelah mendapatkan nilai matrik yang disederhanakan, sistem melakukan perhitungan normalisasi pada nilai matriks di gambar 4 . Hasil normalisasi terlihat pada gambar 5 di bawah ini:

\begin{tabular}{|c|c|c|c|c|c|c|c|}
\hline \multicolumn{8}{|c|}{ MATTRIKS PEMDOBOTAN IIERARCIY YANG DISEDERПANAKAN } \\
\hline MATRIK & DKV & ANIMASI & MULTIMEDIA & TKJ & RPL & JUMLAH & RERATA \\
\hline DKY & 1 & $0,0,5$ & 0,33 & 0,25 & (0,2) & 0,07 & 0,33 \\
\hline ANIVLASI & 2 & 1 & 0,67 & 0,5 & 0,4 & 0,13 & 0,67 \\
\hline MTITTIMFIDIA & 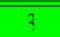 & 15 & 1 & 0.75 & 0.6 & 02 & 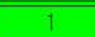 \\
\hline TKJ & 4 & 2 & 1,33 & 1 & 0.8 & 0,27 & 1,33 \\
\hline RPL & 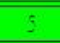 & 2,5 & 1,67 & 1,25 & 1 & 033 & 1.67 \\
\hline
\end{tabular}

Gbr.5 Matrik Pembobotan Yang Dinormalkan

Untuk mendapatkan kebenaran dari perhitungan, maka nilai CI harus rendah dari 0,1 sehingga sistem akan melakukan perhitungan dengan hasil perhitungan seperti gambar di bawah

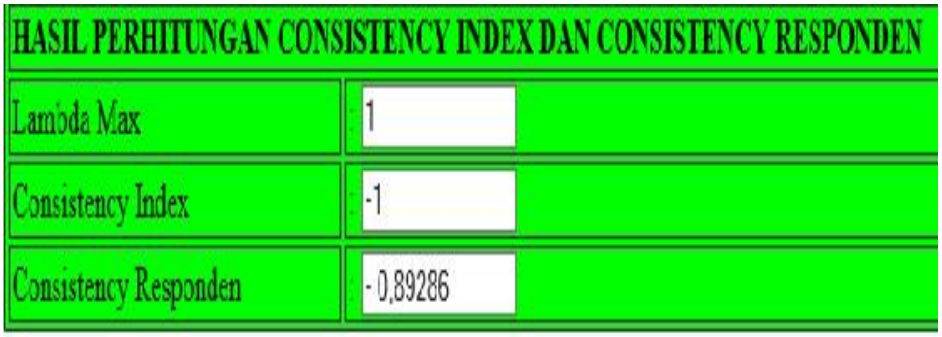

Gbr.6 Hasil Perhitungan Consistency Index

Administrator sistem harus mengelompokkan setiap mata kuliah yang ada pada kurikulum berdasarkan kompetensi paket keahlian yang ada di Sekolah Menengah Kejuruan (SMK). Pengelompokkan ini bertujuan untuk memudahkan proses seleksi sehingga mendapatkan alternatif kompetensi yang masuk sebagai sekolah tujuan kegiatan Program PPL berdasarkan nilai dari indeks komulatif mahasiswa.

\begin{tabular}{|c|c|}
\hline NAMA MATA KULIAH & KOMPETENSI DI SMK \\
\hline Sistem Operasi & Teknik Komputer Jaringan $\vee$ \\
\hline Teknologi Multimedia & Multimedia \\
\hline Struktur Data & Rekayasa Perangkat Lunak $\vee$ \\
\hline Jaringan Komputer Dasar & Teknik Komputer Jaringan $\vee$ \\
\hline Basis Data & Rekayasa Perangkat Lunak $\vee$ \\
\hline Komputer Grafik & Persiapan Grafika \\
\hline Logika Matematika & Rekayasa Perangkat Lunak $\checkmark$ \\
\hline
\end{tabular}

Gbr.7 Pengelompokkan Mata Kuliah Berdasarkan Kompetensi Paket Keahlian

Dengan indikator - indikator pendukung penentuan keputusan yang terdiri dari:

1. Mata kuliah yang telah dikelompokkan berdasarkan kompetensi paket keahlian di Sekolah Menengah Kejuruan wilayah Pekanbaru.

2. Penentuan jumlah mahasiswa yang dikirim per kompetensi paket keahlian.

Maka dilanjutkan dengan melakukan : 
1. Menyeleksi mahasiswa yang akan dikirim ke setiap kompetensi paket keahlian berdasarkan besarnya nilai yang berhubungan dengan setiap kompetensi paket keahlian yang ada. Penyeleksian dilakukan oleh sistem berdasarkan komulatif nilai indeks prestasi setiap mahasiswa.

2. Menentukan sekolah yang akan dikirim berdasarkan usulan dari sistem

Untuk mendapatkan hubungan data kompetensi dan data sekolah maka data sekolah beserta kompetensi paket keahlian yang dimiliki wajib diinput kedalam sistem untuk melengkapi variabel kebutuhan informasi pada sistem informasi seperti yang terlihat pada gambar di bawah ini.

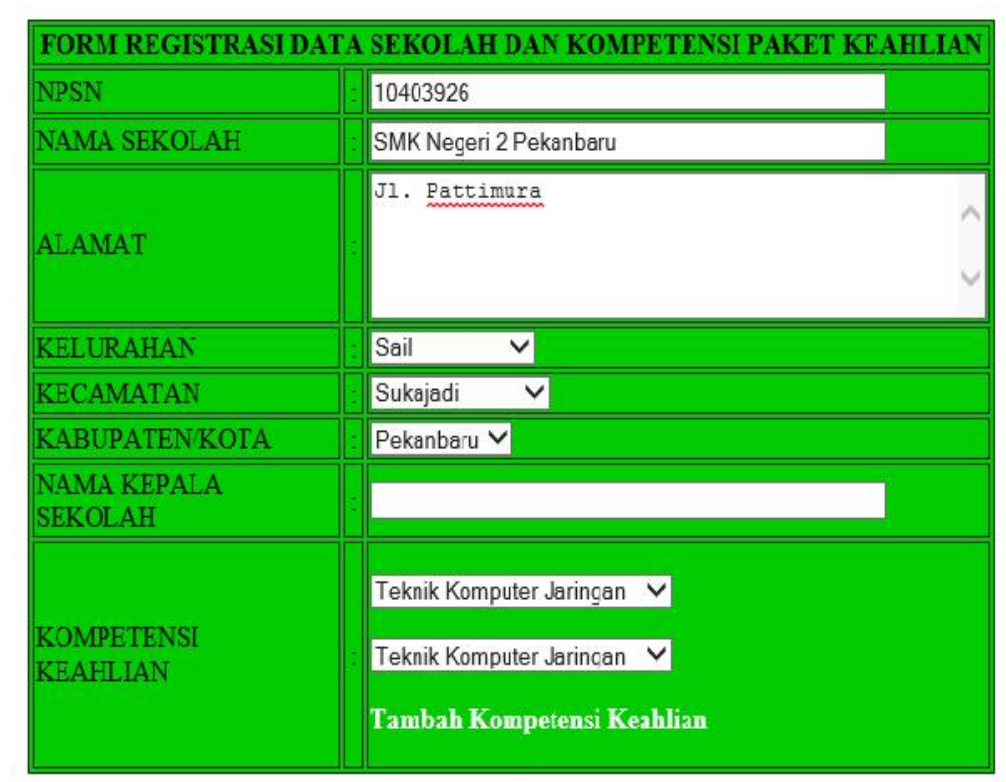

Gbr.8 Registrasi Data Sekolah dan Kompetensi Paket Keahlian

Setelah melakukan registrasi data sekolah yang menjadi tujuan program PPL, selanjutnya melakukan penentuan sekolah yang akan dikirim peserta PPL yang lulus seleksi seperti terlihat pada gambar dibawah ini.

\begin{tabular}{|c|c|c|c|}
\hline \multicolumn{3}{|c|}{ TAHUN PELAKSANAAN PPL FKIP } & $2016-2017 \checkmark$ \\
\hline NO. & NAMA SEKOLAH & DATA KOMPETENSI & AKSI PENENTUAN \\
\hline 1. & SMK Negeri 1 Pekanbaru & Teknik Komputer dan Jaringan & $\checkmark \mathrm{Ya} \square$ Tidak \\
\hline 2. & SMK Negeri 2 Pekanbaru & Rekayasa Perangkat Lunak & $\checkmark Y_{a} \square$ Tidak \\
\hline 3. & & Teknik Komputer dan Jaringan & $\checkmark$ Ya $\square$ Tidak \\
\hline 4. & SMK Negeri 3 Pekanbaru & Multimedia & $\checkmark$ Ya $\square$ Tidak \\
\hline 5. & SMK Negeri 4 Pekanbaru & Desain Komunikasi Visual & $\checkmark$ Ya $\square$ Tidak \\
\hline 6. & SMK Negeri 6 Pekanbaru & Rekayasa Perangkat Lunak & $\checkmark$ Ya $\square$ Tidak \\
\hline 7. & & Teknik Komputer dan Jaringan & $\checkmark$ Ya $\square$ Tidak \\
\hline 8. & & Persiapan Grafika & $\checkmark \mathrm{Ya} \square$ Tidak \\
\hline 9. & SMK Negeri 7 Pekanbaru & Multimedia & $\checkmark$ Ya $\square$ Tidak \\
\hline 10. & & Rekayasa Perangkat Lunak & $\checkmark \mathrm{Ya} \square$ Tidak \\
\hline 11. & & Teknik Komputer dan Jaringan & $\checkmark$ Ya $\square$ Tidak \\
\hline
\end{tabular}


Gbr.9 Penentuan Sekolah dan Kompetensi Yang Dituju Pada PPL

Dengan melakukan pengelompokkan mata kuliah berdasarkan kompetensi paket keahlian, akan menghasilkan komulatif nilai berdasarkan kompetensi paket keahlian seperti yang terlihat pada gambar 10 .

\begin{tabular}{|c|c|c|c|c|c|c|c|c|}
\hline \multirow{2}{*}{$\mathrm{N}_{0}$} & \multirow{2}{*}{ Nama Mahasiswa } & \multicolumn{2}{|l|}{ Dpsi 1} & \multicolumn{2}{|l|}{ חpsi 2} & \multicolumn{2}{|l|}{ Dpki 3} & \multirow{2}{*}{-Seliolah Yang Diusulka } \\
\hline & & Kompeleusi & Silai & Kompelemsi & Nilai & Kompelensi & Nilai & \\
\hline 1 & Alỵa Andriani & RPL & 3.13 & Animasi & 3.25 & DKV & 3.19 & SMK Muhsmmadivah 2 \\
\hline 2 & Diah Ekka Rama & RPL & 3.43 & Animasi & 3.38 & DKV & 3.1 ? & SMK Muhammadivah 2 \\
\hline 3 & Liz Ardani Nasution & RPL & 3.42 & Animasi & 3.13 & $\mathrm{DKV}$ & 2.83 & SMKK Negeri 2 Pekanbaru \\
\hline 4 & lengku Helnt & RPL & 3.42 & Anumas: & 325 & DKV & $3.1 !$ & SMK Negeri 2 Pekanbaru \\
\hline$\vdots$ & Sridevi Malinita & RPT, & 378 & Animasi & 325 & DKV & $31 ?$ & SMK Swasta I à่or \\
\hline 6 & Arman Ridwarsyai & RPL & 3.23 & Animas: & 3.00 & TKJ & 2.70 & SMKK Swasta Labor \\
\hline$i$ & Joti Blas lanti & $\mathrm{KHL}$ & 3.22 & Anmas: & 3.13 & $\mathrm{TKJ}$ & 3.00 & SMK Swasta Labor \\
\hline 8 & Fitriaxati & TKJ & 3.38 & Animasi & 325 & DKV & $3.1 ?$ & SMKK Swasta Kansai \\
\hline 9 & Rahmawati & TKJ & 3.38 & Animasi & 3.25 & DKV & $3.1 ?$ & SMK Swasta Kantas: \\
\hline 10 & Kukı Andresta Putr & IKJ & 3.21 & Anumas: & 3.25 & DKV & $3.1 !$ & SMK Swasta Labor \\
\hline 11 & Yul: Nel:i & TKJ & 3.27 & RPL & 3.20 & Animasi & 3.19 & SMK Negeri 2 Pekanbaru \\
\hline 12 & Nur Safirah & TKJ & 3.27 & Multimedia & 3.25 & $\mathrm{RPL}$ & 3.19 & SMK Muhammadiyah 2 \\
\hline 13 & Anita Putri & Multimedia & 3.21 & RPI & 3.20 & Animasi & 2.53 & SMK Negeri 3 Pekanbaru \\
\hline 14 & Rerii Oklavia & Multuredia & 3.27 & Arimlsi & 3.13 & DKV & 3.00 & SMKK Nequri 3 Pekaribanu \\
\hline 15 & Surianda Kinasti & Multimodia & 3.27 & RPL & 3.15 & Animasi & 3.13 & $\begin{array}{l}\text { SMK Swasta Darel } \\
\text { Hikmah }\end{array}$ \\
\hline 16 & Yald: Defrianda & Multimedia & 3.16 & RPL & 3.15 & Animasi & 3.00 & $\begin{array}{l}\text { SMK Swasta Larel } \\
\text { Hikmah }\end{array}$ \\
\hline 17 & Yuliani & Animasi & 375 & DKV & 317 & RPT. & 294 & SMKK Negeri 7 Pekanhanı \\
\hline 18 & Pupul Reza & Arimesi & 3.13 & DKV & 300 & RPL & 2.92 & SIMK Nequi 7 Pekaribanu \\
\hline 19 & Amaliya Gusniati & Animasi & 3.00 & RPL & 2.88 & DKV & 2.83 & SMK Negeri 7 Pekanbaru \\
\hline 20 & Tesya Gustia & DKV & 3.08 & Animasi & 3.19 & RPL & 2.85 & SMKK Negeri 4 Pekanbaru \\
\hline
\end{tabular}

Gbr.10 Pengelompokkan mahasiswa berdasarkan komulatif nilai kompetensi paket keahlian.

\section{REFERENSI}

[1] N. Fred and T. M. Salvatore, "Design Science and The Accumulation of Knowledge in The Information Systems Discipline", ACM TMIS Journal, vol. 3, no. 1, (2012), April

[2] S. A. Alan and T. R. Cliff, "A Decision Support System For Patient Scheduling in Travel Vaccine Administration", Decision Support Systems Elsevier Publisher, vol. 54, Issue 1, (2012) December, pp. 215-225.

[3] L. Reeva and B. J. Robert, "Decision Support or Support for Situated Choice: Lessons for System Design from Effective Manual Systems", European Journal of Information Systems, (2011) April 19, pp. 510-528.

[4] Direktorat Jendral Manajemen Pendidikan Dasar dan Menengah Department Pendidikan Indonesia, "Spektrum Keahlian Pendidikan Menengah Kejuruan, Keputusan Direktorat Jendral Manajemen Pendidikan Dasar dan Menengah Department Pendidikan Indonesia, no.251/C/KEP/MN/2008", (2008) Agustus

[5] Direktorat Jendral Pendidikan Dasar dan Menengah, "Keputusan Direktur Jenderal Pendidikan Dasar dan Menengah tentang Spektrum Keahlian Pendidikan Menengah Kejuruan nomor 4678/D/KEP/MK/2016", (2016) September.

[6] Krupes A Chauhan, N.C. Shah and R. Venkata Rao, "The Analytical Hierarchy Process as a Decision - Support System In the Housing Sector : A Case Study", World Applied Sciences Journal, (2008) pp. $609-613$.

[7] Adriyeni and Melia Yeni, "DSS Using AHP in Selection of Lecturer", International Journal of Advanced Science and Technology, (2013) March, pp. 35-44

[8] Saaty.T.L, "Decision Making for Leaders. Pittburgh : RWS Publications, (1990) 
[9] Keputusaan Direktorat Jenderal Pendidikan Dasar dan Menengah Nomor:130/D/KEP/KR/201 Tentang Struktur Kurikulum Pendidikan Menengah Kejuruan, (2017) Februari.

[10] Cristina Ofelia Stanciu, "Decision Support Systems Architectures", Annals Computer Science Series $7^{\text {th }}, \mathbf{( 2 0 0 9 )}$, pp. $341-348$ 